\title{
Creating an Efficient Financial System: Challenges in a Global Economy
}

\author{
Thorsten Beck
}

\begin{abstract}
Financial sector development fosters economic growth and reduces poverty by widening and broadening access to finance and allocating society's savings more efficiently. This paper first discusses three pillars on which sound and efficient financial systems are built: macroeconomic stability and an effective and reliable contractual and informational frameworks. The paper then describes three different approaches to government involvement in the financial sector: the laissez-faire view, the market-failure view and the market-enabling view. Finally, the paper analyzes the sequencing of financial sector reforms and discusses the benefits and challenges that emerging markets face when opening their financial systems to international capital markets.
\end{abstract}

World Bank Policy Research Working Paper 3856, February 2006

The Policy Research Working Paper Series disseminates the findings of work in progress to encourage the exchange of ideas about development issues. An objective of the series is to get the findings out quickly, even if the presentations are less than fully polished. The papers carry the names of the authors and should be cited accordingly. The findings, interpretations, and conclusions expressed in this paper are entirely those of the authors. They do not necessarily represent the view of the World Bank, its Executive Directors, or the countries they represent. Policy Research Working Papers are available online at http://econ.worldbank.org.

* The author is with the World Bank's research department. This paper was written for the G20 Seminar on Economic Growth in Pretoria, August 2005. The author is grateful to Robert Cull, Asli Demirguc-Kunt and Patrick Honohan for useful comments and Ed AlHussainy for outstanding support. 


\section{Finance: pro-growth and pro-poor}

Financial markets and institutions arise to alleviate market frictions that prevent the direct pooling of society's savings and channeling to investment projects. Well developed financial systems ease the exchange of goods and services by providing payment services; help mobilize and pool savings from a large number of investors; acquire and process information about enterprises and possible investment projects, thus allocating society's savings to their most productive use; monitor investments and exert corporate governance; and help diversify and reduce liquidity and intertemporal risk (Levine, 1997 and 2005). However, there is a large variation across countries in the efficiency with which financial institutions and markets reduce transaction costs and information asymmetries, with important repercussions for economic growth and development. Private credit to GDP was $173 \%$ in the U.S. in 2003, but only $2 \%$ in Mozambique. ${ }^{1}$ While financial institutions in the U.S. have recently introduced 40 year mortgage loans, in many developing countries lending for housing is restricted to five year loans if at all available. While in Albania there are four loans per 1,000 people, there are almost 800 loans per 1,000 people in Poland (Beck, Demirguc-Kunt and Martinez Peria, 2005). While interest rate spreads - the difference between lending and deposit rates - vary typically between $2 \%$ and $4 \%$ in developed financial systems, they are over 30\% in Brazil (Laeven and Majnoni, 2005).

Countries with better developed financial systems, i.e. financial markets and institutions that more effectively channel society's savings to their most productive use, experience faster economic growth. ${ }^{2}$ Figure 1 summarizes a well-established body of empirical evidence; countries with higher levels of credit to the private sector relative to GDP experienced higher average annual real GDP per capita growth rates over the period 1980 to 2003. This relationship

\footnotetext{
${ }^{1}$ Private Credit to GDP is a standard measure of financial intermediary development and is the ratio of claims by deposit money banks and other financial institutions on the private, domestic non-financial sector to GDP.

${ }^{2}$ To be sure, there is also a feedback of faster economic growth on the development of the financial system.
} 
is not only robust to controlling for other factors that are associated with economic growth, but is also robust to controlling for the reverse causation from faster economic growth to financial development and to the relationship being driven by a third factor. While Figure 1 shows the relationship between private sector lending and GDP per capita growth, other measures of financial development, such as the ratio of M2 to GDP or the turnover ratio in stock markets, yield similar results (Levine, Loayza and Beck, 2000; Beck and Levine, 2004). These findings are confirmed by cross-country, panel and by time-series estimation techniques (see Levine, 2005, for an overview).

Financial sector development helps economic growth through more efficient resource allocation and productivity growth rather than through the scale of investment or savings mobilization (Beck, Levine and Loayza, 2000). Finance fosters economic development by widening access to external finance and helping those industries and firms most reliant on external financial resources (Demirguc-Kunt and Maksimovic, 1998; Rajan and Zingales, 1998), as well as by allowing smaller firms to overcome financing constraints and grow faster (Beck, Demirguc-Kunt and Maksimovic, 2005; Beck, Demirguc-Kunt, Laeven and Levine, 2004). Finance improves resource allocation and increases the efficiency with which investment funds are reallocated across industries as demand changes (Love, 2003 and Wurgler, 2000). Financial development has also an important role in dampening the impact of external shocks on the domestic economy (Beck, Lundberg and Majnoni, 2006; Aghion, Banerjee and Manova, 2005; Raddatz, 2006). The development of the financial sector is a decisive determinant of the structure of the trade balance, giving countries a comparative advantage in manufacturing and within manufacturing in those industries most dependent on external finance (Beck, 2002, 2003). Finally, recent cross-country evidence has shown that it is the lowest income quintile that stands to gain most from financial development; by reducing income inequality and fostering economic growth, financial markets and institutions help reduce poverty (Beck, Demirguc-Kunt and 
Levine, 2004, Honohan, 2004). Figure 2 illustrates the empirical cross-country relationship between the level of financial intermediary development and poverty reduction: countries with higher levels of private credit to GDP experienced faster reductions in the share of the population living on less than one dollar a day over the 1980s and 1990s. There is thus no trade-off between pro-growth and pro-poor in the case of policies that enhance a sound and efficient financial system.

While Figures 1 and 2 show the importance of private sector lending for economic growth and poverty alleviation, private credit is not a policy variable itself. To the contrary, bigger is not always better! A rapid increase in private sector lending, not supported by the macroeconomic, contractual and informational framework discussed below, can result in fragility and banking crises, as experienced by many countries over the past 30 years (Demirguc-Kunt and Detragiache, 1999; Caprio and Klingebiel, 1997). ${ }^{3}$

While policy makers and academics have long discussed the relative benefits of the Anglo-Saxon style market-based, arms-length financial system vs. the German-Japanese style relationship, bank-based system, cross-country evidence has not confirmed the importance of financial structure for economic development. It is the provision of financial services, rather than who provides them that matters for economic development (Beck and Levine, 2002; Demirguc-Kunt and Maksimovic, 2002; Levine, 2002). This does not imply that financial structure - the degree to which markets or banks provide financial services - does not vary with economic and financial development; financial markets gain in importance relative to banks as financial systems develop (Boyd and Smith, 1998; Demirguc-Kunt and Levine, 2001). However, there is no evidence that systematically favoring the development of banks over securities markets or the converse will speed financial and economic development. The focus should

\footnotetext{
${ }^{3}$ See Demirguc-Kunt and Detragiache (2005) for an overview over the crisis containment and resolution literature. See Loayza and Ranciere (2005) and Ranciere, Tornell and Westerman (2005) for an empirical investigation of the trade-offs between financial development and crisis.
} 
rather be on the underlying policies and institutions that allow both banks and markets to effectively intermediate society's savings.

Given the importance of financial development for economic growth and poverty reduction, policy makers and academics alike are interested in the building blocks for a sound and effective financial system. The next section will discuss three important policy areas for financial sector development and cross-country experience in these areas: macroeconomic stability and an effective and reliable contractual and informational framework. What, however, is the role of government in the financial sector, if any? Section 3 describes three different approaches to government involvement in the financial sector: the laissez-faire view, the marketfailure view and the market-enabling view. Few if any financial sector reforms can be implemented overnight, which raises the question of sequencing and prioritizing. Section 4 offers some lessons on implementing and sequencing of financial sector reforms. Section 5 addresses the challenges arising for policy makers in the financial sector in a more and more globalized world and section 6 concludes.

The analysis and policy recommendations discussed in the remainder of this paper are based on cross-country comparisons, and on past success stories and failures. It is important to note, however, that this paper represents the best judgment based on current knowledge and empirical research and should not be seen as a dogma that has been definitely settled for all times. While I try to cover a broad range of issues, there are areas that I cannot cover. More specifically, I will relate to international finance only to the extent that they affect domestic financial intermediation, but not touch on macroeconomic aspects of financial integration. 


\section{Pillars of an effective and stable financial system}

This section discusses three building blocks for a sound and effective financial system. Cross-country analysis and specific country examples have shown the importance of macroeconomic stability and of the contractual and informational frameworks. ${ }^{4}$ Similarly, the market structure and the financial safety net and more specifically the regulation and supervision of institutions and markets are important for deepening and broadening; the discussion of these items, however, will be left to the next section where I discuss the role of government.

Financial contracts consist of an exchange of money today for the promise of money tomorrow, thus an enormous leap of faith into an uncertain future. The intertemporal nature of the contract and several market frictions make financial contracts critically different from other contracts in a market-based economy. First, there is uncertainty whether today's contracted repayment (such as interest or insurance payout) or expected repayment (such as dividends or capital gains in the case of equity claims) will be the same in terms of tomorrow's consumption units due to inflation. Second, information asymmetries between borrowers and lenders make the assessment of viable investment projects difficult and lead to principal-agent problems and moral hazard risk, i.e. the possibility that the borrower will not act in the best interest of the lender. Similarly, market frictions prevent the costless enforcement of contracts, again increasing incentives for borrowers to deviate from contracted promises. ${ }^{5}$

These market frictions give rise to financial institutions and markets. Financial institutions take on the role of “delegated monitors” (Diamond, 1984) for savers vis-à-vis borrowers; financial markets allow the transformation of claims on multi-year illiquid investment projects into liquid tradable securities. Financial institutions acquire and process information about the creditworthiness of their borrowers and the success probabilities of their investment

\footnotetext{
${ }^{4}$ There is also an extensive literature on historic determinants of financial sector development, such as the colonial experience, and the impact of political institutions on finance. See Beck and Levine (2005) for an overview.

${ }^{5}$ See Levine $(1997,2005)$ for an overview over theoretical models discussing these market frictions.
} 
projects, effectively doing so on behalf of their depositors, while prices in financial markets reflect the evaluation of diverse investors of the issuers' business prospects. While market participants have developed techniques to overcome market frictions, their efficiency critically depends on the macroeconomic stability and an effective contractual and informational framework, as we will discuss in the following.

\subsection{Macroeconomic stability}

Given the intertemporal character of financial contracts, macroeconomic stability is a prerequisite for financial development and a first building block for an effective financial system. A low and stable rate of inflation provides incentives for financial rather than non-financial forms of savings. It is also conducive to long-term contracting and thus long-term savings and investment by providing monetary certainty. Savers are more likely to entrust their savings for a given interest rate if they can be ensured the expected return in terms of real consumption units. Similarly, monetary stability allows investors to adequately compute the return on projects and commit to payments in real terms. Theory and empirical cross-country comparisons have shown that countries with lower and more stable inflation rates experience higher levels of banking and stock market development (Boyd, Levine and Smith, 2001). This is illustrated in Figure 3, which plots Private Credit to GDP over the period 1980 to 2003 against the average annual inflation rate for the same period. Further, high inflation is correlated with a higher probability of systemic banking distress (Demirguc-Kunt and Detragiache, 2005). Similarly, a controlled fiscal government deficit can enhance financial sector deepening by avoiding crowding-out effects of government spending needs on private sector lending and investment. 


\subsection{Contractual framework}

Financial contracts depend on the certainty of legal rights of borrowers, creditors and outside investors and the predictability and speed of their fair and impartial enforcement. Private property rights and enforcement of contracts - both vis-à-vis other private parties and vis-à-vis the government - are thus a second crucial pillar of an effective financial system. Savers are only willing to relinquish control over their savings if they can be sure to receive principal and contracted interest in return. Outside financiers - be they equity or debt holders - will only be willing to invest in companies and projects if their legal claims and rights are upheld. This points to both creditor rights and minority shareholder rights as being critical for external financing, as well as the role of corporate governance in both financial institutions and non-financial corporations. Shareholders do not only need sufficient information, but also the possibility to influence company decisions directly through votes on critical corporate decisions and indirectly by determining members of the Board of Directors that will ensure that management acts in the best interest of the equity holders. Critical in the relationship between minority shareholders and controlling shareholder and management are often problems of looting and of tunneling, i.e. the possibility for the controlling shareholder to move assets outside the firms, and the remedial actions that the legal system offers minority shareholders against it (Johnson et al., 2000). Creditors will have to be ensured of the fair and quick enforcement of their contracts if the borrower defaults. This implies the possibility of both enforcing contracts outside bankruptcy as well as maintaining creditor rights within the bankruptcy procedure. Effective legal systems

provide for timely, efficient and impartial resolution of insolvent borrowers through the efficient liquidation of unviable enterprises and the rehabilitation of viable businesses.

International comparisons have provided ample evidence for the critical role of legal system efficiency and its different elements for financial sector development. Countries with better creditor rights protection and more efficient judicial systems experience higher levels of 
financial development (La Porta et al., 1997; Levine, Loayza and Beck, 2000, Djankov, McLiesh and Shleifer, 2005). Countries whose legal systems more effectively prevent looting of corporations by controlling shareholders suffered milder financial crises in 1997-98 (Acemoglu et al., 2003). More effective legal systems provide for more flexible, adaptable and rapid conflict resolution rather than rigid, lengthy statutorily based processes with positive repercussions for firms’ access to finance (Djankov et al., 2003; Beck, Demirguc-Kunt and Levine, 2005). Cross-country comparisons have shown that financial systems that can rely on more effective legal systems, have lower interest rate spreads and are more efficient (DemirgucKunt, Laeven and Levine, 2004; Laeven and Majnoni, 2005). The effect of legal system efficiency on financial intermediation is illustrated in Figures 4 to 6, where we show the positive relationship between creditor rights and Private Credit to GDP (Figure 4), the negative relationship between the time period it takes to enforce contracts and Private Credit to GDP (Figure 5) and the positive relationship between better protection of minority shareholder rights and the stock market capitalization to GDP (Figure 6). ${ }^{6}$

\subsection{Informational framework}

As financial markets and institutions arise due to information asymmetries that prevent direct interaction between multiple savers and investors, effective financial intermediation depends on tools to reduce these information asymmetries. The informational framework is thus a third fundamental requirement for effective financial intermediation. International experience has shown that the sharing of credit information sharing is important to reduce adverse selection problems and foster competition in the financial system. Credit registries that give easy and reliable access to clients’ credit history and both negative and positive information can

\footnotetext{
${ }^{6}$ There is a literature that discusses the direct impact of property right protection and contract enforcement on entrepreneurs' investment decisions and firm growth (Johnson, McMillan and Woodruff, 2002, Claessens and Laeven, 2003; Cull and Xu, 2005).
} 
dramatically reduce the time and costs of obtaining such information from individual sources and therefore reduce the total costs of financial intermediation. Credit reporting makes borrower quality much more transparent, which benefits good borrowers and increases the cost of defaulting on one’s obligations. It helps borrowers build up a credit history - "reputation collateral” - and thus eases access to credit. Credit registries are especially important for SMEs as their creditworthiness is harder to evaluate and they have less visibility and transparency relative to large enterprises. Consumer rights to access their information and challenge erroneous information have to be effectively protected to make such a system a widely acceptable part of the financial system infrastructure and balance consumer rights with efficiency considerations. International comparisons have shown that countries with better developed systems of credit information sharing enjoy higher levels of financial development and their firms report lower financing obstacles (Jappelli and Pagano, 2002; Love and Mylenko, 2003; Djankov, McLiesh and Shleifer, 2005; see Miller, 2003, for an overview). Figure 7 illustrates the positive relationship between the efficiency of credit information sharing and Private Credit to GDP.

While many countries have built up credit information systems within their central bank or supervisory authority as part of their early warning system to monitor financial institutions, it is important to keep in mind the effect of credit information sharing on the competitiveness of the financial sector and on access to credit; this, however, implies the inclusion of all claims independent of their size, the inclusion of all financial institutions and even non-financial institutions such as utility companies to reap the maximum benefit. Further, effective credit information systems can form the basis for the more effective use of technology in credit decision processes, such as credit scoring techniques.

Similarly, more accurate and transparent financial statements can help reduce information asymmetries between borrowers and lenders. Financial statements that give an accurate picture 
of a firm's financial situation reduce screening and monitoring costs for financial institutions and increase the efficiency of resource allocation. Cross-country comparisons have shown a positive association of more transparent and comprehensive accounting standards with higher levels of financial development (Levine, Loayza and Beck, 2000 and La Porta et al., 1997). Similarly, transparent and more informative financial statements lower information costs for equity investors and can foster stock market development and liquidity (Levine, 2003).

While the policy recommendations for the contractual and informational framework seem somewhat biased towards external fund providers rather than users, policy makers have to keep in mind that the long-term interests of users would not be served if deficiencies in the underlying rules make would-be-providers withhold their funds. Lower information asymmetries strengthen the position of borrowers vis-à-vis lenders; similarly, stronger property rights allow borrowers to use their assets more effectively as collateral and thus negotiating card in their relationship with lenders.

\section{The role of government in financial service provision}

The role of the government in financial service provision has been controversial. While most economists agree by now on the role of government in providing a stable monetary environment and at least some government involvement in the contractual and informational framework, there has been an ongoing debate over the past decades on the role of government as financial service provider and on the regulation and supervision of financial service providers by government. This section presents three different approaches to government involvement in the financial sector: the laissez-faire view, the market-failure view and the market-enabling view. 


\subsection{The laissez-faire approach}

Under the laissez-faire or invisible-hand approach, there is no role for government involvement in the financial system. Market discipline rules the relationship between banks and depositors and between banks and borrowers. Depositors and creditors of financial institutions monitor them and exercise market discipline by either withdrawing funds or demanding higher interest rates. Failing banks are taken over by more successful banks or are liquidated. Similarly, banks monitor and discipline borrowers; borrowers unable or unwilling to repay are liquidated or rehabilitated through a restructuring process. Under the pure laissez-faire approach, there is thus no role for government involvement.

A modified laissez-faire approach stresses the importance of macroeconomic stability and the contractual and informational framework and might see a role for government in providing these necessary infrastructure elements for financial intermediation.

The laissez-faire approach has been criticized for ignoring market imperfections and failures that lead to a break-down of bank-depositor and bank-borrower relationships as envisioned in theory. Depositors are not able to monitor banks as they do not have the means to do so or the costs are too high relative to the claims vis-à-vis the banks. Especially small depositors have to be protected against loss of their life-time savings. Banks, on the other hand, have to be protected against runs by uninformed depositors that would force liquidation of longterm investment projects financed by bank loans. There are also market frictions in the bankborrower relationship that prevent optimal resource allocation. ${ }^{7}$ Financial institutions might not necessarily invest in the sectors with the highest social return. Banks- due to their role as debt holders -are claimed to have an inherent bias toward conservative low-risk low return investments, stymieing innovation and growth. By acquiring inside information about firms, powerful banks can extract informational rents from firms, thus reducing their incentives to

\footnotetext{
${ }^{7}$ See Levine (2005) for a more detailed discussion.
} 
undertake profitable investments. Further, short-term profit-oriented banks might force borrowers into bankruptcy that suffer only from short-term liquidity problems or they might not even lend to borrowers with projects that require a long gestation period.

\subsection{From market- to government failures}

Given market failures in the financial systems, governments in many developed and emerging economies took a very active if not interventionist role in the financial system in the 1960s and 1970s. ${ }^{8}$ Through ownership of financial institutions governments hoped to enhance savings mobilization, direct credit to priority sectors, and make financial services affordable to larger parts of the population. Through ceilings on lending interest rates governments hoped to reduce lending costs for borrowers, while floors for deposits interest rate were to provide incentives to savers. Credit quotas imposed even on private providers were supposed to guarantee that financial resources flowed to priority and underserved sectors, such as agriculture and small-scale enterprises. Through specialized institutions, such as agricultural banks or housing finance companies, governments hoped to provide more financial resources for these sectors.

The financial safety net also became an important part of government intervention in the financial system. Powerful supervisors were supposed to not only prevent fragility, but also guide banks in their business decisions through regulation and supervision. Deposit insurance was introduced in many countries to prevent bank runs and protect small savers. In many cases, through the dominating presence of government-owned banks and politically connected private banks, this limited explicit guarantee was extended to an implicit guarantee for all bank creditors and depositors and often even owners of financial institutions.

\footnotetext{
${ }^{8}$ See Fry (1988) for a discussion of these policies and numerous examples.
} 
Government solutions to overcome market failures rely on two crucial assumptions.

First, governments know better than markets, and, second, governments act in the best interest of society. Both assumptions relate to the public-interest view, the idea that public authorities maximize social welfare and have the necessary tools to do so. ${ }^{9}$ Both assumptions have been proven wrong across the developed and developing world. Bureaucrats have turned out to have limited knowledge and expertise to run financial institutions and systems and they do not maximize society’s welfare, but are rather subject to political and regulatory capture, i.e. influence by the political sphere and the regulated entities, as hypothesized by the private-interest view.

Bureaucrats as bankers have failed almost everywhere, but especially in developing countries; economies with a higher share of government-owned banks experience lower levels of financial development, more concentrated lending and lower economic growth and are more likely to suffer systemic fragility (La Porta et al, 2002; Barth, Caprio and Levine, 2004). This is illustrated in Figure 8, which shows the negative association of Private Credit to GDP with the share of majority government-owned banks in the banking system. Bureaucrats have neither the market knowledge nor the right incentives to properly screen and monitor borrowers and thus ensure the allocation of society's savings to its most productive use. Being owner, borrower and regulator of an institution at the same time, governments face obvious conflicts of interest. Experience in many countries has shown that government-owned banks are often used by politicians to finance commercially unviable government projects or state-owned enterprises. Politicians use government-owned banks for electoral purposes; experience across developing countries has pointed to increased lending in election years and especially to contested districts (Cole, 2005; Dinc, 2005). The resulting non-performing loans (NPLs) have resulted in large

\footnotetext{
${ }^{9}$ For a in-depth discussion on the public- and private interest views in the context of financial regulation and supervision, see Barth, Caprio and Levine (2006).
} 
fiscal costs and often in banking crises (Barth, Caprio and Levine, 2004; Caprio and Martinez Peria, 2002). Further, the negative impact of government-owned banks spreads often beyond these institutions to the rest of the sector: there are efficiency losses as private sector banks face less competition and governance problems often spread beyond government-owned banks. An explicit guarantee for government-owned banks is often equated with an implicit guarantee for privately-owned banks. Cross-country comparisons have shown that there are fewer possibilities for the private sector to monitor in countries with a higher share of government-owned banks (Caprio and Honohan, 2004).

Worse than government ownership, however, can be a failed privatization process. Poorly designed and executed privatization processes can lead to fragility and banking crises as numerous examples have shown over the past 30 years. Studies of privatization processes have shown the benefits of privatizing government-owned banks, but also the pitfalls (compare Clarke, Cull and Shirley 2005, and other papers in the same issue). Among the lessons learned from privatization of government-owned banks around the globe are that it is important to open the books early in the process to thus make the cost of continuous government ownership to the taxpayer clear to the public and thus potentially create political pressure for privatization. However, this also points to the recommendation to not recapitalize a bank before privatizing to thus not ease the political pressure to privatize. While privatization should not be delayed to minimize fiscal and efficiency losses, fire sales might lead to privatizations to investors that are not fit and proper or have not adequately assessed the situation of the bank, which might result in subsequent fragility. There are advantages to divest to a strategic investor who can bring the necessary management and financial know-how, especially in weak institutional environment and to open the privatization process to both qualified domestic and foreign bidders. By selling to reputable foreign banks, financial systems can benefit from expertise and from additional resources. Finally, country studies have shown the advantages of full rather than partial 
privatization to reduce possible future government influence. By giving up any ownership stake, government signals that it does not plan to intervene after privatization and that it will not bail out the new private investors should things go wrong. Privatization, however, is not a panacea, as privatizing into a non-competitive environment where other elements of the framework discussed earlier are not in place will not necessarily bring benefits in terms of more private sector lending.

Credit quotas and interest caps and floors have impeded the efficient allocation of society’s savings to its most productive uses and have especially hurt “smaller” depositors and borrowers (Fry, 1988). In case of binding ceilings, banks are prevented from charging adequate risk premiums for riskier and more opaque borrowers or from recovering fixed transaction costs through a mark-up on smaller loan amounts. Further, competition between credit institutions and for more deposits is hampered as financial institutions have no incentives to become more efficient or to attract more deposits if they cannot finance more marginal customers. Similarly, given fixed transaction costs in financial intermediation, floors on deposit interest rates make savers with small transaction amount unattractive for financial institutions. Credit quotas have resulted in fragmentation of credit markets and higher costs for non-priority sectors. In many cases, financial institutions have found ways around these restrictions, but at a high costs and with consequent efficiency losses.

While many countries have adopted systems of deposit insurance over the past decades with the intent to reduce the risks of bank runs, protect small depositors and thus create a stable and sound banking system, the moral hazard risks coupled with weak regulatory and supervisory frameworks have often resulted in the opposite. By bailing out not only small, but also large depositors and creditors, poorly designed deposit insurance schemes have reduced market discipline, which in the absence of effective bank supervision has often resulted in imprudent and unchecked risk taking by banks with subsequent fragility (Demirguc-Kunt and Detragiache, 
2002; Demirguc-Kunt and Huizinga, 2004). Further, cross-country comparisons have not confirmed the assertion that deposit insurance is crucial for financial sector development; to the opposite, countries with more generous deposit insurance schemes are found to have lower levels of financial savings and private sector lending (Cull, Senbet and Sorge, 2005).

While strengthening of supervisors' intervention powers has been at the forefront of efforts improving the supervisory framework, there is little cross-country evidence that empowering supervisors alone will bring stability. There is evidence, however, that powerful bank supervisors might be associated with higher levels of corruption. Beck, Demirguc-Kunt and Levine (2006a) show that firms in countries with more powerful bank supervisors, i.e. supervisors that directly monitor, discipline, and influence banks, are more likely to report major obstacles due to corruption in lending. On the other hand, a supervisory strategy that focuses on empowering private monitoring of banks by forcing banks to disclose accurate information to the private sector tends to lower the degree to which corruption of bank officials is an obstacle to firms raising external finance.

\subsection{Enabling markets - a new approach}

Rather than replacing market failures with government failures, policies are required that address market failures directly and try to reduce market frictions. This new approach is not a laissez-faire approach as it does not leave the market to itself; rather, it relies on the government to enable and develop markets. It starts from the observation that frictions might prevent markets from functioning well or might even prevent markets from existing in the first place. However, this approach does not seek to replace missing or poorly functioning markets, but rather create the conditions for markets to emerge and function properly. It relies on private institutions to provide financial services efficiently but takes into account their incentive structure. This approach foresees a government that works with the market, but does not leave it to the market. 
Rather, it provides the framework that enables private agents to contract by ensuring macroeconomic stability and an effective contractual and informational framework. However, it also considers incentives; by enabling and fostering market discipline, it minimizes aggressive risk taking by bank owners and managers.

While the government should not be a direct provider of financial services under this new approach, it has a critical role in ensuring a competitive and contestable financial system. Crosscountry comparisons have shown that countries with lower entry barriers into the financial system, fewer restrictions on banking and a higher share of foreign-owned banks have more competitive, more efficient and more stable banking systems (Claessens and Laeven, 2004; Beck, Demirguc-Kunt and Maksimovic, 2004, Demirguc-Kunt, Laeven, Levine, 2004; Beck, Demirguc-Kunt and Levine, 2006b). Allowing or even encouraging entry by sound and prudent new institutions, whether they be domestic or foreign, is important to maintain contestability. But the role of the government might have to be even more active. The setting up of credit reference bureaus, for example, often requires involvement of the government to overcome resistance by financial institutions as especially the sharing of positive information can diminish information rents of incumbent banks. Avoiding segmentation in the financial sector through expanding access to the payment system or the credit information sharing system beyond the commercial banks to bank-like institutions such as cooperatives or regulated microfinance institutions can help the financial system cater to marginal customers in all financial services. The financial safety net plays a critical role in supporting a stable and effective banking system. Given the maturity transformation - using deposits withdrawable at short notice to finance medium- to long-term loans - and given the limited transparency of financial institutions, banks have been subject to special regulation and supervision not applied to non-financial corporations. Given the put-option character of bank equity, bank shareholders participate only in the up-side risk of the bank business and have therefore strong incentives to take too 
aggressive risks, ignoring sound and prudent risk management. Effective bank regulation and supervision, as well as market discipline exercised by large depositors and creditors can keep bank owners and managers in check.

While there is little evidence that empowering intervention powers of bank supervisors enhances bank stability, there is evidence that enabling the private sector to monitor and discipline banks has positive repercussions for the efficiency, stability and overall development of the financial system (Barth, Caprio and Levine, 2004). Further, private sector monitoring can have both direct and indirect positive effects on financial stability (Caprio and Honohan, 2004). Monitoring and disciplining by market participants such as large depositors and other creditors has the advantage of many eyes instead of just one as in the case of supervisors; further, many eyes might be less subject to political pressure than the supervisory authority. In addition, market signals in the form of deposit interest rates, yields on subordinated debt or equity prices of publicly listed banks moving in response to risk taking and performance of banks provide additional information to bank supervisors to act on. This signaling mechanism can only work, of course, if coupled with effective official intervention into institutions that the market has identified as weak. The interaction of market and supervisory monitoring and disciplining can thus be powerful in reigning in bankers’ incentives to take aggressive risks. La Porta, Lopez-deSilanes and Shleifer (2006) find a similarly positive effect of private monitoring and disciplining for stock market development; laws that mandate disclosure and facilitate private enforcement through liability rules foster stock market development, while there is little evidence for a positive effect of public enforcement.

Political independence and accountability and protection of supervisors from frivolous law suits by financial institutions and others are important to prevent political and regulatory capture. Most importantly, however, is the lack of a government guarantee for shareholders or 
large depositors or creditors as this undermines the incentives to monitor banks and consequently the market prices reflecting banks’ risk taking.

While the finding that explicit deposit insurance is associated with more rather than less bank fragility does not necessarily imply an abandonment of the idea of deposit insurance in countries where it already exists, careful design and timing of the introduction of deposit insurance is critical. Limited coverage and exclusion of certain groups can create a class of creditors - such as holders of subordinated debt, other financial institutions, insiders or large corporations - that have the means to monitor banks and exercise market discipline. Aligning the interests and incentives of banks and the managers and owners of the deposit insurance scheme by funding and administering the scheme privately, with limited if any government back-up funding, can further reduce moral hazard risks. Finally, linking the deposit insurance scheme effectively to the bank failure resolution system can be critical in reducing the moral hazard risk induced by explicit deposit insurance and in fostering market and supervisory discipline (Beck and Laeven, 2006). The main objective of an incentive-compatible bank failure resolution system is the protection of financial intermediation, i.e. small depositors, borrower-lender relationships and the payment system, rather than to protect an individual institution and its shareholders.

\section{Sequencing of financial sector reforms}

Building a sound and effective financial system cannot be achieved overnight, but rather requires a mix of short-term policy measures, medium-term reform processes and long-term institution building. Abolishing interest rate ceilings and floors, eliminating directed credit programs and imposing transparency requirements are policy reforms that can be speedily legislated, regulated and implemented, as the experience in many developed and developing 
countries has shown. Other processes can take longer, such as privatizing government-owned banks and establishing a system of credit information sharing. Reforming legal systems and building regulatory and supervisory capacity are long-term institution building processes.

Given that different reform measures can be undertaken only at different speeds, it is important to consider the interdependence of these different reforms; should all reforms be undertaken as soon as they can, independent of how fast results can be achieved or should reforms be timed so that their results can be achieved at approximately the same time? This seemingly technical discussion is not independent of political considerations. On the one hand, implementing some reforms rapidly can result in a certain momentum to avoid reversal.

Liberalizing financial markets can create contestability and a group of winners with a stake in further reform. Achieving some early gains can thus create momentum for further reforms. On the other hand, implementing reforms hastily and without taking into account the interdependence of reforms in different areas can lead to fragility or disappointments and thus a backlash against the original reforms and even more against further reforms.

Many countries have liberalized and privatized in the 1980s and 1990s with mixed results. In the absence or the slow implementation of institution building, many economies have faced systemic financial fragility in subsequent years (Demirguc-Kunt and Detragiache, 1999). Weak regulatory and supervisory frameworks, combined with generous explicit deposit insurance or an implicit guarantee by governments have resulted in aggressive risk taking by banks, unchecked by market or supervisory discipline, often without the necessary lending skills and the necessary contractual and informational framework. Banking crises in Argentina, Chile, and Mexico in 1980s and 1990s have been attributed to these factors. These lending booms together with economic volatility have often resulted in systemic fragility with banking and even currency crises as consequence. This post-liberalization experience has been very ably summarized by Diaz Alejandro as “Good-Bye Financial Repression, Hello Financial Crash” 
(Diaz Alejandro, 1985). Many Sub-Saharan African countries, on the other hand, that have opened their banking systems to reputable foreign banks, often through the privatization of failed government banks, and have liberalized interest rates and credit allocation, have experienced more stability and efficiency but also less intermediation and less access to financial services. In the absence of an effective contractual and informational framework and thus lending opportunities at a reasonable risk-return combination, banks have preferred to invest in government securities or abroad. This has often led to claims of failed financial liberalization processes and the renewed calls for government interventions in the financial sector.

Limited gains in financial intermediation or financial fragility following liberalization of financial markets do not necessarily signal the failure of financial sector reform, but they carry important lessons. These experiences underline the importance of liberalization at a pace consistent with regulatory and supervisory capacity in the country. Imposing temporary restrictions on certain activities with a clear timetable to eventually abolish them might help. It is important to align the incentives with the risks. Better possibilities for bankers to take risks and earn higher returns have to come with the clear understanding that they cannot shift the risks over to depositors or taxpayers. Similarly, the reform process has to be handled with the right expectations. While market-based financial service provision is a necessary, it is not a sufficient condition for deep and broad financial systems. Governments have an important role in enabling markets by providing for competition as well as in creating markets by reforming the contractual and informational framework that allows provision of financial services beyond the few rich, well-known and connected. While relying on private providers and the market price mechanism as basic fundaments of the financial sector, the economy at large can only reap the benefits of a sound and effective financial system if the necessary infrastructure elements are in place.

The disappointment with the reform outcomes, however, also carries important repercussions for the discussion on the role of government in the financial sector. The 
disappointment with financial sector reforms have often led to calls for renewed government intervention in the financial sector, either by re-establishing government-owned financial institutions or by a "tighter” financial safety net. While this would be a step back, it underlines the necessity for government to take a more "pro-active” role by considering specific bottlenecks that prevent private agents to provide financial services even if macroeconomic stability, contractual and informational efficiency and free entry into financial intermediation have been achieved. It underlines the role of government in enabling and creating markets, as discussed in section 3.3; a discussion, however, that is just starting and that will be informed by trials and errors.

\section{Challenges for financial systems in a global economy}

One important aspect of liberalizing financial systems is liberalizing financial flows across borders. This implies both free entry of foreign providers and the possibility for agents to purchase financial services abroad. It implies free capital flows in the form of debt and equity between foreign and domestic agents across borders and within countries. In the following, I will touch briefly on some aspects of international financial liberalization as they refer to the financial sector and financial sector policies; for broader discussions of these issues, see Clarke et al. (2003) and Bekaert and Harvey (2003).

More and more developed and emerging economies allow the entry of foreign financial service providers, with so diverse countries as Botswana, Czech Republic, Hungary and Mexico and Poland seeing foreign-owned banks take more than $80 \%$ of the banking market. ${ }^{10}$ In many developing countries, foreign bank entry has mostly occurred through the privatization process of failed government-owned or private domestic banks, with the hope that foreign banks bring in

\footnotetext{
${ }^{10}$ Data are for end 2001; source: Barth, Caprio and Levine (2006).
} 
not only resources but through higher efficiency also more competitive pressure on the domestic banking sector. On the other hand, concerns have been expressed that a larger presence of foreign banks might reduce access to credit especially for SMEs, as these firms rely more on relationship lending.

Cross-country evidence has confirmed that foreign-owned banks are more efficient than domestic banks in developing countries and that foreign bank entry does indeed exert competitive pressure on domestic banks to become more efficient (Claessens, Demirguc-Kunt and Huizinga, 2001). While there is some evidence that foreign banks might have the potential to transmit shocks from the home to their host countries, their lending does generally not decline during financial crises in their host countries (Dages, Goldber and Kinney, 2000; Peek and Rosengren, 2000). The empirical evidence on the effect of foreign bank entry on access to credit has been at most mixed if not favorable. On the one hand, borrowers in countries with higher foreign bank presence report lower financing obstacles and are more likely to have access to bank credit (Clarke, Cull and Martinez Peria, 2001). Foreign bank entry helps reduce related lending and its negative effects on resource allocation (Giannetti and Ongena, 2005; Bonin and Imai, 2005). On the other hand, research on specific developing countries has shown that foreign-owned banks are less likely to lend to more opaque borrowers and rely more on hard rather than soft information (Mian, 2003). However, evidence from Eastern Europe has shown that while foreign banks tend to initially focus on large corporate clients, they go down market over time, increasing retail and small business lending (De Haas and Naaborg, 2005) While the debate on domestic versus foreign banks has often focused on relationship vs. transaction-based lending techniques, recent evidence shows that as new transaction-based lending techniques, such as leasing, factoring and credit scoring, have been developed, relationship lending has become less important for SME lending (Berger and Udell, 2006). These techniques, however, 
might require certain expertise and fixed start-up costs, which gives large and potentially foreign-owned banks an advantage over smaller domestic banks.

Foreign bank entry can help, but is not sufficient to improve the efficiency of intermediation and the availability of credit. The presence of dominant government-owned banks reduces competitive pressures; the absence of a sound contractual and informational framework reduces the feasibility of small business lending. ${ }^{11}$ The absence of other important elements of the financial infrastructure thus impedes countries from reaping the full benefits of opening their markets to foreign providers of financial services.

International capital flows have increased substantially over the past years, especially portfolio flows and foreign direct investment. More and more emerging markets have decided to open their economies for inward and outward equity and debt investment. Allowing outward investment helps private agents diversify investment and earn a higher return at lower risk. This is especially important for mutual and pension funds with limited long-term investment possibilities in the local markets. These limitations on investment and risk diversification possibilities are especially striking for small economies with limited domestic possibilities of risk diversification and high risk economies (Driessen and Laeven, 2005). Allowing inward investment can help attract additional resources and improve resource allocation. Cross-country comparisons have shown that countries experience higher capital inflows, lower cost of capital for enterprises raising funds through stock exchanges, higher investment growth, improved capital allocation and ultimately higher GDP per capita growth rates after opening their economies to equity inflows (Bekaert and Harvey, 2003). While countries have experienced more volatile asset price movements in the years following liberalization (Kaminsky and Schmukler, 2003), concerns that higher capital inflows after financial liberalization lead to higher volatility in the form of investment boom-and-bust cycles have not been confirmed by the

\footnotetext{
${ }^{11}$ See Beck and Fuchs for a discussion in the context of Kenya (2004).
} 
data (Bekaert and Harvey, 2003). While participation of foreign investors can increase the vulnerability of domestic markets to contagion from shocks in other countries as foreign investors re-organize their portfolios, evidence has shown that foreign investors are less likely to withdraw their money first in times of crisis and their trading activity has no destabilizing effect on their host countries’ capital markets.

Stock market reforms and capital account opening can have ambiguous effects on domestic stock markets. Allowing domestic firms to raise resources abroad, through ADRs or cross-listing on international stock exchanges allows these firms to raise additional resources. Recent research, however, has also shown a reduction in trading activity of these firms on domestic stock exchanges and a negative spill-over effect on the liquidity of other firms that do not go abroad (Levine and Schmukler, 2005). Similarly, international comparisons of the effect of capital market related reforms have shown a negative impact on trading on domestic markets as these reforms make domestic firms more attractive to international investors and thus allow them access to international markets (De la Torre, Gozzi Valdes and Schmukler, 2005). While this seems like a disappointing consequence of financial liberalization, policy makers have to remember that it is the access to financial services that matters not who provides the service or where it is provided.

Even more than equity flows, debt flows, especially short-term debt flows, can have an immediate effect on interest and exchange rates of emerging and industrial economies. While a liberalized financial system can function without a completely open capital account and thus liberalized cross-border debt flows, opening the capital account makes controls on domestic interest rates and credit flows difficult if not impossible to sustain and counterproductive and damaging, as large depositors and borrowers have the possibilities to circumvent them by investing and borrowing abroad. As capital account liberalization has exposed economies to substantial volatility in capital flows and macroeconomic prices, a consensus has developed to 
sequence capital account liberalization, for example by opening first for longer-term investment before opening to short-term flows. Similarly, taxes on inflows can help reduce volatility, as the example of Chile has shown. ${ }^{12}$ Recent research has also shown that capital inflows through foreign bank local claims are less volatile than if they are in the form of cross-border claims (Garcia Herrero and Martinez Peria, 2005).

Exchange rate risk has become of increasing importance for financial intermediation as many emerging countries have experienced increasing degrees of dollarization of their financial systems, i.e. both savings and lending in foreign rather than the local currency. Capital account liberalization has complicated this problem further as capital flow volatility and the accompanying exchange rate volatility increases risk for financial intermediaries, be it price or default risk, while at the same time complicating the task in macroeconomic management for policy makers. It is important to understand, however, that dollarization is not a problem per se, but rather the endogenous response to underlying weaknesses in the economy, notably weak domestic currencies and volatile real exchange rates (de la Torre and Schmukler, 2005; de Nicoló, Honohan and Ize, 2003). Similarly to the focus on short-term contracts and contracting under foreign jurisdictions, contracting in foreign currency is a risk-coping mechanism; however, an instrument that brings new risks with it. While financial contracts in foreign currency reduce price risk, they increase price-induced default risk, especially the risk of producers of nontradable goods to not be able to repay dollar loans, as experienced in recent crises. Policy makers thus face a steep trade-off between restricting the use of foreign currency and thus eliminating this risk-coping instrument with the results of a depressed domestic financial system and a move to off-shore banking, or allowing financial contracting with the volatility and the risks for financial intermediation and monetary management it brings with it. In case of allowing

\footnotetext{
${ }^{12}$ However, see critical view by Forbes (2002) who points to lower access to external financing by smaller firms in Chile due to restricted capital inflows.
} 
dollarization of financial systems, policy makers face the tension between allowing changes in nominal exchange rates to manage the economy appropriately and the costs of widespread default of borrowers in case of abrupt changes in nominal exchange rates. While the discussion is still on-going, financial economists have pointed to a three-pronged approach that accepts the use of financial contracting in foreign currency while managing its risks. Specifically, this approach focuses on exchange rate flexibility with inflation targeting, the adjustment of prudential regulation so that banks internalize the additional risks foreign currency loans carry and the development of alternative methods of indexing. Crucial, however, seems to be to prevent the impression of implicit insurance for financial institutions; otherwise, financial institutions would rely on the government to bail them out in the case that exchange rate changes cause financial distress. This could thus result in fear of floating on the side of authorities.

\section{Conclusions}

Building the foundations for a stable and effective financial system implies short-term policy measures, medium-term reform processes and long-term institution building. Theoretical and empirical research has pointed to the importance of macroeconomic stability and of an effective and reliable contractual and informational framework as critical fundamentals for financial intermediation. Experience with financial sector policies in developed and emerging markets also offer valuable lessons on the role of government in the financial systems. Bureaucrats as providers of financial services and as operators of financial systems have failed almost everywhere. However, this experience does not imply a laissez-faire approach; rather it implies a critical and active role for government in enabling and creating markets, by ensuring competitive and contestable banking and capital markets and providing an incentive-compatible financial safety net. Defining a proper role for government is even more important as more and 
more countries embrace open capital accounts, which increases pressures to remove domestic policy distortions and liberalize markets.

While empirical research has provided substantial evidence on what policies have worked and which have not, much less evidence is available on the proper sequencing of reforms. While no model fits all sizes and country experiences, some lessons for policy makers can be drawn. First, markets should be liberalized to the extent that there are capacities to harness market forces. The regulatory and supervisory capacities as well as the possibilities for markets to exercise discipline should keep up with the possibilities of financial institutions to take risk. Second, authorities should try to stay incentive compatible throughout the reform process. Most importantly, unlimited explicit or implicit insurance should be avoided for depositors, creditors and especially owners of financial institutions. Third, the authorities should stay transparent and accountable throughout the whole process. This is especially important in politically sensitive and economically significant transactions such as privatization and licensing processes. Finally, authorities should manage expectations on the risks and rewards of financial reforms. The policy reforms discussed in this paper are necessary, not sufficient, conditions for a sound and effective financial system; only their effective interaction can create the basis for a growthenhancing financial sector.

The empirical research and policy recommendations discussed in this paper present the best judgment based on current knowledge. As new, more micro-based, data become available and researchers are able to empirically assess the effect of specific policy reforms, economists will not only be able to endorse or reject specific policy recommendations, but will also be able to better quantify the effect of specific reforms and policy changes. ${ }^{13}$ Technological change, especially in information technology, and further international integration promise to transform

\footnotetext{
${ }^{13}$ See Haselmann, Pistor and Vig (2006) as example for Eastern Europe, where they find that reforms of creditor rights outside bankruptcy have a significant effect on private sector lending, while bankruptcy reform does not.
} 
the financial system substantially over the coming decades, providing new opportunities for providers and users of financial services and new challenges for researchers and policy makers. 


\section{References}

Acemoglu, D., Johnson, R., Robinson, J.A., and Thaicharoen, Y. 2003. "Institutional Causes, Macroeconomic Symptoms: Volatility, Crises and Growth.” Journal of Monetary Economics 50, 49-123.

Aghion, P., Angeletos, G-M., Banerjee, A., and Manova, K. 2004. "Volatility and Growth: Credit Constraint and Productivity-Enhancing Investment.” NBER Working Paper 11349.

Barth, J., Caprio, G., and Levine, R. 2006. Rethinking Bank Regulation: Till Angels Govern. Cambridge University Press.

Barth, J., Caprio, G., and Levine, R. 2004. "Bank Regulation and Supervision: What Works Best?” Journal of Financial Intermediation 13, 205-48.

Beck, T. 2003. “Financial Dependence and International Trade.” Review of International Economics 11, 296-316.

Beck, T. 2002. “Financial Development and International Trade. Is There a Link?” Journal of International Economics 57, 107-31.

Beck, T., Demirguc-Kunt, A., Laeven, L., and Levine, R. 2004. "Finance, Firm Size, and Growth.” World Bank Policy Research Working Paper 3485.

Beck, T; Demirguc-Kunt, A., and Levine, R. 2006a. "Bank Supervision and Corruption in Lending.” Journal of Monetary Economics, forthcoming.

Beck, T; Demirguc-Kunt, A., and Levine, R. 2006b. Bank Concentration and Crises: First Results.” Journal of Banking and Finance, forthcoming.

Beck, T., Demirguc-Kunt, A., and Levine, R. 2005. "Law and Firms’ Access to Finance." American Law and Economics Review 7, 211-52.

Beck, T., Demirguc-Kunt, A., and Levine, R. 2004. "Finance, Inequality and Poverty: CrossCountry Evidence.” World Bank Policy Research Working Paper 3338.

Beck, T., Demirguc-Kunt, A., and Maksimovic, V. 2005. "Financial and Legal Constraints to Firm Growth: Does Firm Size Matter?” Journal of Finance 60, 137-77.

Beck, T., Demirguc-Kunt, A., and Maksimovic, V. 2004. "Bank Competition and Access to Finance: International Evidence.” Journal of Money, Banking, and Credit 36, 627-48.

Beck, T., Demirguc-Kunt, A., and Martinez Peria, M. 2005. "Reaching Out: Access to and Use of Banking Services Across Countries.” World Bank Policy Research Working Paper 3754.

Beck, T. and Fuchs, M. 2004. 'Structural Issues in the Kenyan Financial System: Improving Competition and Access, World Bank Policy Research Working Paper 3363.

Beck, T. and Laeven, L. 2006. Who Should Resolve Failing Banks? World Bank mimeo.

Beck, T., and Levine, R. 2005. "Legal Institutions and Financial Development.” In: Menard, C. and Shirley, M. (eds.), Handbook of New Institutional Economics. Kluwer Dordrecht.

Beck, T., and Levine, R. 2004. “Stock Markets, Banks and Growth: Panel Evidence.” Journal of Banking and Finance 28, 423-42.

Beck, T., and Levine, R. 2002. "Industry Growth and Capital Allocation: Does Having a Marketor Bank-Based System Matter?” Journal of Financial Economics 57, $107-31$. 
Beck, T., Levine, R., and Loayza, N. 2000. "Finance and the Sources of Growth.” Journal of Financial Economics 58, 261-300.

Beck, T., Lundberg, M., and Majnoni, G. 2006. "Financial Intermediary Development and Growth Volatility: Do Intermediaries Dampen or Magnify Shocks.” Journal of International Money and Finance, forthcoming.

Bekaert, G., and Harvey, C. 2003. “Emerging Markets Finance.” Journal of Empirical Finance 10, 3-56.

Berger, A., and Udell, G.F. “A More Complete Conceptual Framework for Financing of Small and Medium Enterprises.” Journal of Banking and Finance, forthcoming.

Bonin, J., and Imai, M. 2005. “Soft Related Lending: A Tale of Two Korean Banks.” Wesleyan University mimeo.

Boyd, J.H., Levine, R., and Smith, B.D. 2001. “The Impact of Inflation on Financial Sector Performance.” Journal of Monetary Economics 47, 221-48.

Boyd, J.H., and Smith, B.D. 1998. "The Evolution of Debt and Equity Markets in Economic Development.” Economic Theory 12, 519-60.

Caprio, G., and Honohan, P. 2004. “Can the Unsophisticated Market Provide Discipline?” World Bank Policy Research Working Paper No. 3364.

Caprio, G., and Klingebiel, D. 1997. Bank Insolvency: Bad Luck, Bad Policy, or Bad Banking?, in: Bruno, M. and Pleskovic, B. (Eds.): Annual Bank Conference on Development Economics 1996, The World Bank, 29-62.

Caprio, G., and Martinez Peria, M. 2002. “Avoiding Disasters: Policies to Reduce the Risk of Banking Crises.” In: Cardoso, E. and Galal, A. (eds.), Monetary Policy and Exchange Rate Regimes: Options for the Middle East. The Egyptian Center for Economic Studies, Cairo, Egypt.

Claessens, S., Demirguc-Kunt, A., and Huizinga, H. 2001. ”How Does Foreign Bank Entry Affect Domestic Banking Markets?” Journal of Banking and Finance 25, 891-911.

Claessens, S., and Laeven, L. 2004. "What Drives Bank Competition? Some International Evidence.” Journal of Money, Credit, and Banking 36, 563-82.

Claessens, S. and Laeven, L. 2003. “Financial Development, Property Rights and Growth.” Journal of Finance 58, 2401-36.

Clarke, G., Cull, R., Martinez Peria, M., and Sanchez, S. 2003. Foreign Bank Entry: Experience, Implications for Developing Economies, and Agenda for Future Research.” World Bank Research Observer 18, 25-59.

Clarke, G., Cull, R., and Martinez Peria, M. 2001. "Does Foreign Bank Penetration Reduce Access to Credit in Developing Countries: Evidence from Asking Borrowers.” World Bank Policy Research Working Paper 2716.

Clarke, G., Cull, R., and Shirley, M. 2005. "Bank Privatization in Developing Countries: A Summary of Lessons and Findings.” Journal of Banking and Finance 29, 1905-30.

Cole, S. 2005. “Fixing Market Failures or Fixing Elections? Elections, Banks, and Agricultural Lending in India.” Harvard Business School mimeo.

Cull, R., Senbet, L., and Sorge, M. 2005. "Deposit Insurance and Financial Development.” Journal of Money, Credit and Banking 37, 43-82. 
Cull, R., and Xu, L. C. 2005. "Institutions, Ownership and Finance: The Determinants of Profit Reinvestment among Chinese Firms.” Journal of Financial Economics 77, 117-46.

Dages, G.B., Goldberg, L., and Kinney, D. 2000. "Foreign and Domestic Bank Participation in Emerging Markets: Lessons from Mexico and Argentina.” Federal Reserve Bank of New York Economic Policy Review 6, 17-36.

De Haas, R., and Naaborg, I. 2005. “Does Foreign Bank Entry Reduce Small Firms’ Access to Credit: Evidence from European Transition Economies, Dutch National Bank Working Paper 50.

De la Torre, A., Gozzi Valdez, J. C., and Schmukler, S. 2005 "Stock Market Development under Globalization: Whither the Gains from Reforms?” World Bank mimeo.

De la Torre, A., and Schmukler, S. 2004. "Coping with Risks Through Mismatches: Domestic and International Financial Contracts for Emerging Economies.” International Finance 7: 349-90.

Demirguc-Kunt, A., and Detragiache, E. 2005. "Cross-Country Empirical Studies of Systemic Banking Distress: A Survey.” In: Davis, P. (ed.), Financial Instability, Asset Prices and Credit. National Institute Economic Review, forthcoming.

Demirguc-Kunt, A., and Detragiache, E. 2002. "Does Deposit Insurance Increase Banking System Stability? An Empirical Investigation.” Journal of Monetary Economics 49:7, 1373-406.

Demirguc-Kunt, A., and Detragiache, E. 1999. "Financial Liberalization and Financial Fragility.” In: Pleskovic, B, and Stiglitz, J. (eds.), Proceedings of the World Bank Annual Conference on Development Economics. Washington, DC.

Demirguc-Kunt, A., and Huizinga, H. 2004. “Market Discipline and Deposit Insurance.” Journal of Monetary Economics 51, 375-99.

Demirguc-Kunt, A., Laeven, L., and Levine, R. 2004. "Regulations, Market Structure, Institutions, and the Cost of Financial Intermediation.” Journal of Money, Credit, and Banking 36, 593-622.

Demirguc-Kunt, A., and Levine, R. 2001. "Bank-Based and Market-Based Financial Systems: Cross-Country Comparisons.” In: Demirguc-Kunt, A., and Levine, R. (eds.), Financial Structure and Economic Growth, MIT Press.

Demirguc-Kunt, A., and Maksimovic, V. 2002. "Funding Growth in Bank-Based and MarketBased Financial Systems: Evidence from Firm-Level Data.” Journal of Financial Economics 65, 337-63.

Demirguc-Kunt, A., and Maksimovic, V. 1998. “Law, Finance and Firm Growth.” Journal of Finance 53, 2107-37.

De Nicoló, G., Honohan, P. and Ize, A. 2003. “Dollarization of the Banking System: Good or Bad?” IMF Working paper 03/146.

Diamond, D. 1984. "Financial Intermediation and Delegated Monitoring.” Review of Economic Studies 51, 393-414.

Diaz Alejandro, C. 1985. “Good Bye Financial Repression, Hello Financial Crash.” Journal of Development Economics 19, 1-24.

Dinc, S. 2005. Politicians and Banks. Political Influences on Government-Owned Banks in Emerging Countries, Journal of Financial Economics 77, 453-79. 
Djankov, S., McLiesh, C., and Shleifer, A. 2005. "Private Credit in 129 Countries.” NBER Working Paper 11078.

Djankov, S., La Porta, R., Lopez-de-Silanes, F., and Shleifer, A. 2003. “Courts: The Lex Mundi Project, Quarterly Journal of Economics 118, 453-517.

Driessen, J., and Laeven, L. 2003. "International Portfolio Diversification Benefits: CrossCountry Evidence from a Local Perspective.” World Bank mimeo.

Forbes, K. 2003. “One Cost of the Chilean Capital Controls: Increased Financial Constraints for Smaller Traded Firms.” NBER Working Paper 9777.

Fry, M.J. 1988. Money, Interest, and Banking in Economic Development. John Hopkins University Press, Baltimore, MD.

Garcia Herrero, A., and Martinez Peria, S. 2005. “The Mix of International Banks’ Foreign Claims: Determinants and Implications.” World Bank Policy Research Working Paper 3755.

Giannetti, M., and Ongena, S. 2005. "Financial Integration and Entrepreneurial Activity: Evidence from Foreign Bank Entry in Emerging Markets.” European Central Bank Working Paper 498.

Haselmann, R., Pistor, K. and Vig, V., 2005, How Law Affects Lending?, Columbia Law and Economics Working Paper 285.

Honohan, P. 2004. "Financial Development, Growth and Poverty: How Close are the Links." In: Goodhart, C. (ed.), Financial Development and Economic Growth: Explaining the Links. London: Palgrave.

Johnson, S., La Porta, R., Lopez-de-Silanes, F., and Shleifer, A. 2000. “Tunneling.” American Economic Review Papers and Proceedings, 22-27.

Johnson, S., McMillan, J., and Woodruff, C. 2002. "Property Rights and Finance.” American Economic Review 92, 1335-1356.

Jappelli, T., and Pagano, M. 2002. "Information Sharing, Lending and Defaults: Cross-Country Evidence.” Journal of Banking and Finance 26:10, 2017-45.

Kaminsky, G., and Schmukler, S., 2003, “Short-term pain, Long-term Gain: The Effect of Financial Liberalization”, NBER Working Paper 9787.

La Porta, R., Lopez-de-Silanes, F., and Shleifer, A 2006. "What Works in Securities Laws?” Journal of Finance, forthcoming.

La Porta, R., Lopez-de-Silanes, F., and Shleifer, A. 2002. "Government Ownership of Commercial Banks.” Journal of Finance 57, 265-301.

La Porta, R., Lopez-de-Silanes, F., Shleifer, A., Vishny, R.W. 1997. "Legal Determinants of External Finance.” Journal of Finance 52, 1131-1150.

Laeven, L and Majnoni, G. 2005. “Does Judicial Efficiency Lower the Cost of Credit?” Journal of Banking and Finance 29, 1791-812.

Levine, R. 2005. "Finance and Growth: Theory and Evidence." In: Aghion, P and Durlauf, S. (eds.), Handbook of Economic Growth. Elsevier Science. The Netherlands.

Levine, R. 2003. “Napoleon, Bourses, and Growth: With a Focus on Latin America.” In: Azfar, O. and Cadwell, C.A. (eds.), Market-Augmenting Government: The Institutional Foundations for Prosperity. University of Michigan Press, Ann Arbor, MI. 
Levine, R. 2002. “Bank-Based or Market-Based Financial Systems: Which is Better?” Journal of Financial Intermediation 11, 1-30.

Levine, R. 1997. "Financial Development and Economic Growth: Views and Agenda.” Journal of Economic Literature 35, 688-726.

Levine, R., Loayza, N. and Beck, T. 2000. "Financial Intermediation and Economic Growth: Causes and Causality.” Journal of Monetary Economics 46, 31-77.

Levine, R., and Schmukler, S. 2005. "Migration, Spillovers, and Trade Diversion: The Impact of Internationalization on Domestic Stock Market Activity.” NBER Working Paper 9614.

Loayza, N., and Ranciere R. 2005. "Financial Development, Financial Fragility, and Growth.” World Bank Policy Research Working Paper 3431.

Love, I. 2003. "Financial Development and Financing Constraints: International Evidence from the Structural Investment Model.” Review of Financial Studies 16, 765-91.

Love, I., and Mylenko, N. 2003. “Credit Reporting and Financing Constraints.” World Bank Policy Research Working Paper 3142.

Mian, A. 2003. "Foreign, Private Domestic, And Government Banks: New Evidence from Emerging Markets.” University of Chicago mimeo.

Miller, M. 2003. Credit Reporting Systems and the International Economy. MIT Press, Cambridge, Mass.

Peek,J., and Rosengren, E.S. 2000. "Implications of the Globalization of the Banking Sector: The Latin American Experience.” Federal Reserve Bank of Boston New England Economic Review, September-October, 45-62.

Raddatz, C. 2006. “Liquidity Needs and Vulnerability to Financial Underdevelopment." Journal of Financial Economics, forthcoming.

Rajan, R., and Zingales, L. 1998. "Financial Dependence and Growth.” American Economic Review 88, 559-587.

Ranciere, R., Tornell, A., and Westerman, F. 2005. "Systemic Crises and Growth.” NBER Working Paper 11076.

World Bank 2005. Doing Business, Washington,. D.C..

Wurgler, J. 2000. "Financial Markets and the Allocation of Capital." Journal of Financial Economics 58, 187-214. 


\section{Figure 1: GDP per Capita Growth and Private Credit}

This graph illustrates a regression of real GDP per capita growth on log of initial GDP per capita, government consumption as share of GDP, trade as share of GDP, black market premium, average years of schooling, inflation and Private Credit. Specifically, this figure represents the two-dimensional representation of the regression plane in GDP per capita growth - Private Credit space. To obtain this figure, we regress GDP per capita growth on all explanatory variables except Private Credit, collect the residuals, and call them (GDP per Capita Growth $\mid \mathrm{X}$ ). Next, we regress Private Credit against all other explanatory variables, collect the residuals, and call them e(Private Credit |X ). Then, we plot e(GDP per Capita Growth |X) against e(Private Credit |X). All data for the regressions are averaged over the period 1980-2003. Private Credit is the claims of financial institutions on the private non-financial sector to GDP.

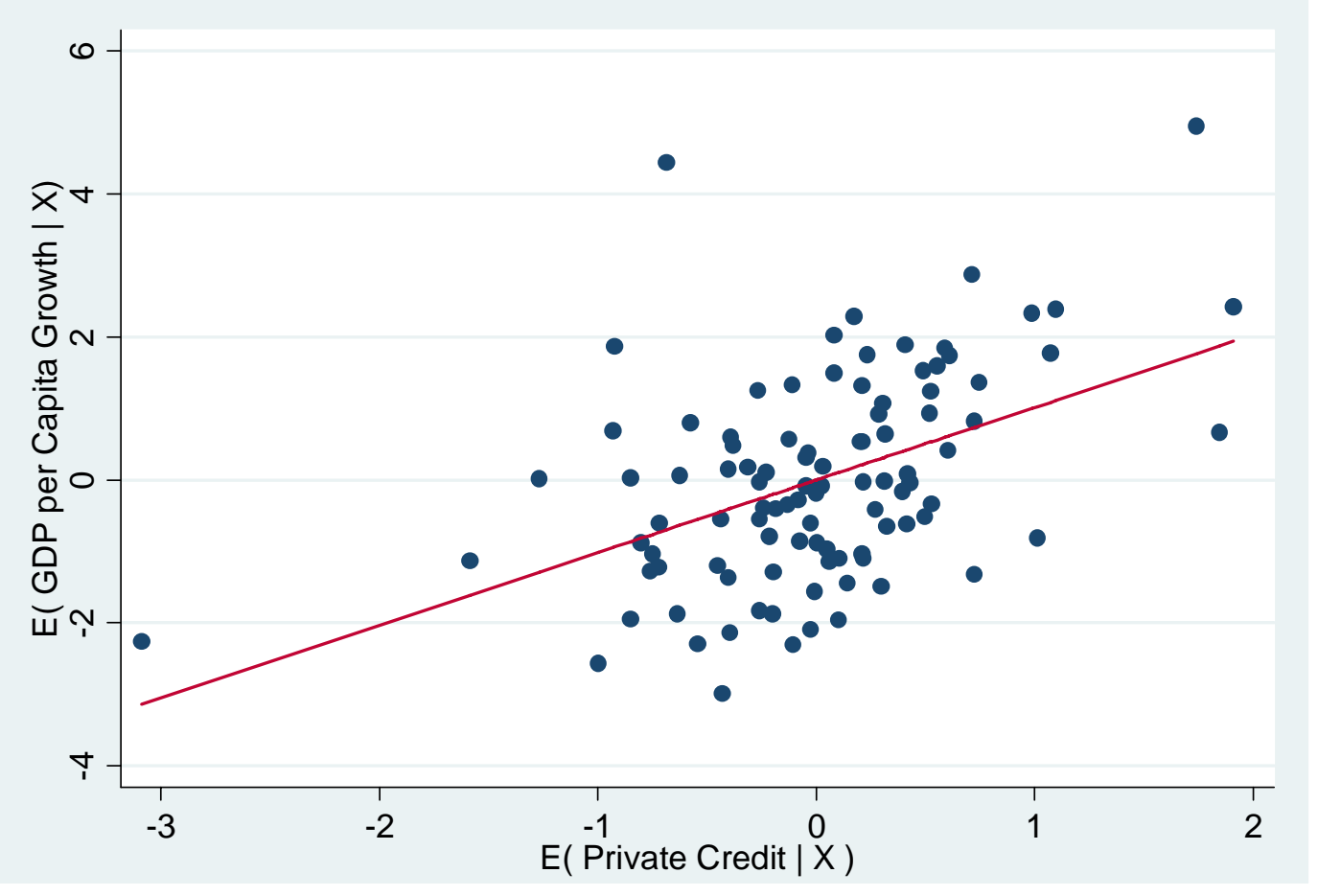




\section{Figure 2: Poverty Alleviation and Private Credit}

This graph illustrates a regression of Growth of Headcount against log of initial Headcount, GDP per capita Growth and Private Credit. Specifically, this figure represents the two-dimensional representation of the regression plane in Growth of Headcount - Private Credit space. To obtain this figure, we regress Growth of Headcount on log of initial Headcount and GDP per capita Growth, collect the residuals, and call them (Growth of Headcount $\mid X$ ). Next, we regress Private Credit against log of initial Headcount and GDP per capita Growth, collect the residuals, and call them e(Private Credit $\mid \mathrm{X})$. Then, we plot e(Growth of Headcount $\mid \mathrm{X})$ against e(Private Credit $\mid \mathrm{X})$. Source: Beck, Demirguc-Kunt and Levine (2004).

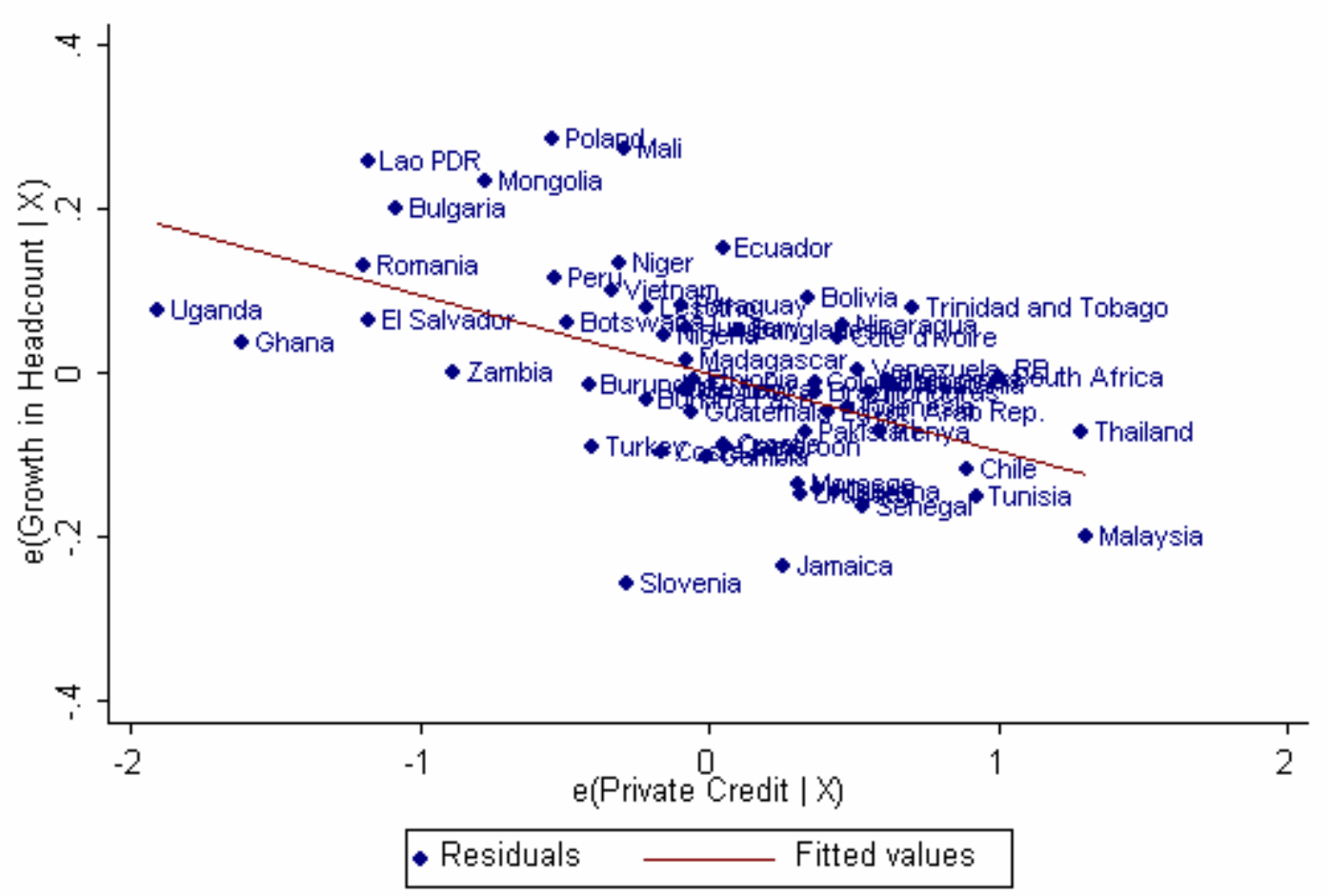


Figure 3: Private Credit and Inflation

Private Credit/GDP is the claims of financial institutions on the private non-financial sector to GDP. Inflation is the log of (1 + average annual CPI inflation). Data averaged for 1980-2003.

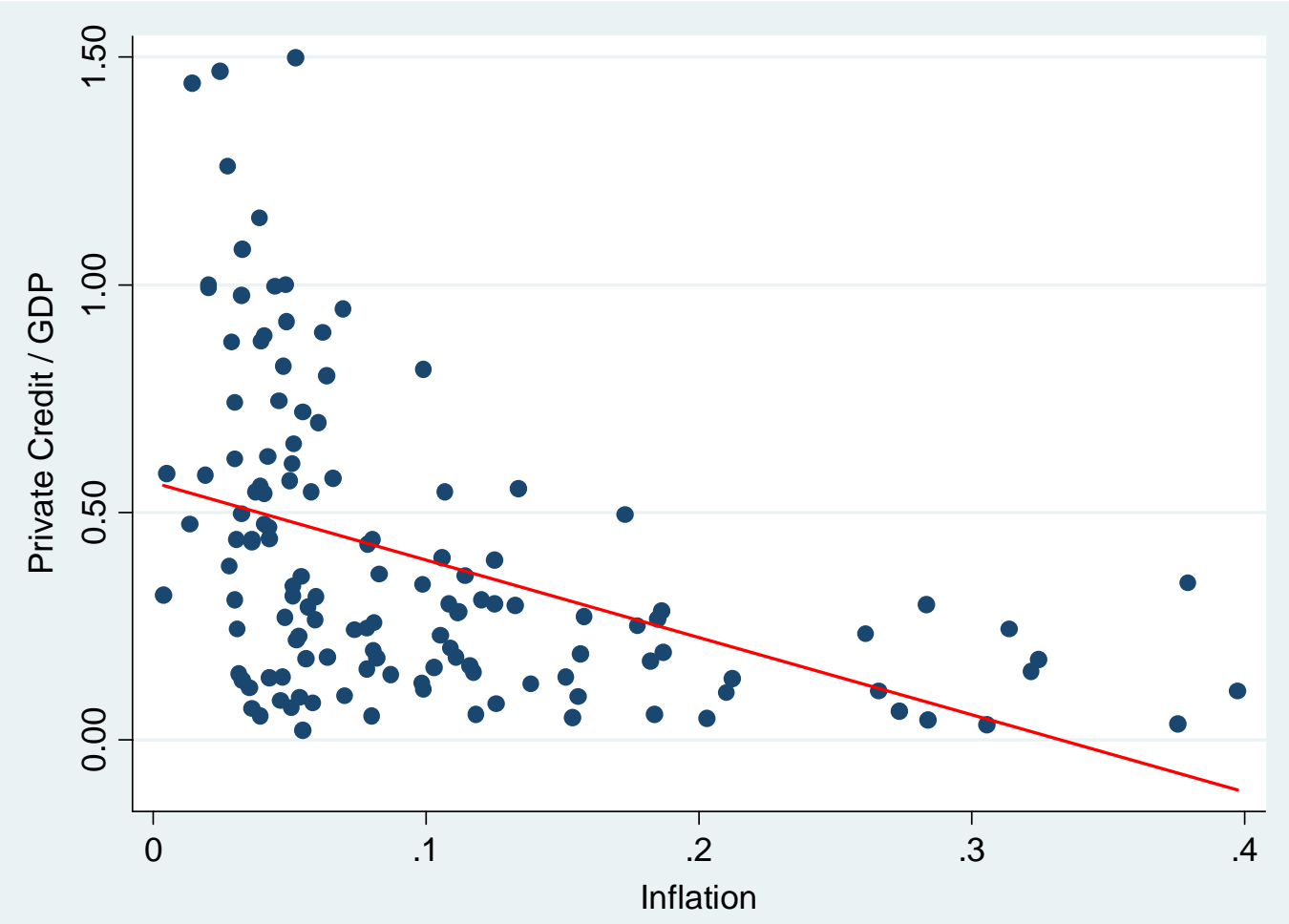




\section{Figure 4: Private Credit and Creditor Rights}

Private Credit/GDP is the claims of financial institutions on the private non-financial sector to GDP. Data averaged for 1980-2003. The Creditor Rights Index reflects the legal rights of borrowers and lenders and measures the degree to which collateral and bankruptcy laws facilitate lending; the index ranges from 0 to 10 , with higher scores indicating that collateral and bankruptcy laws are better designed to expand access to credit (World Bank, 2005).

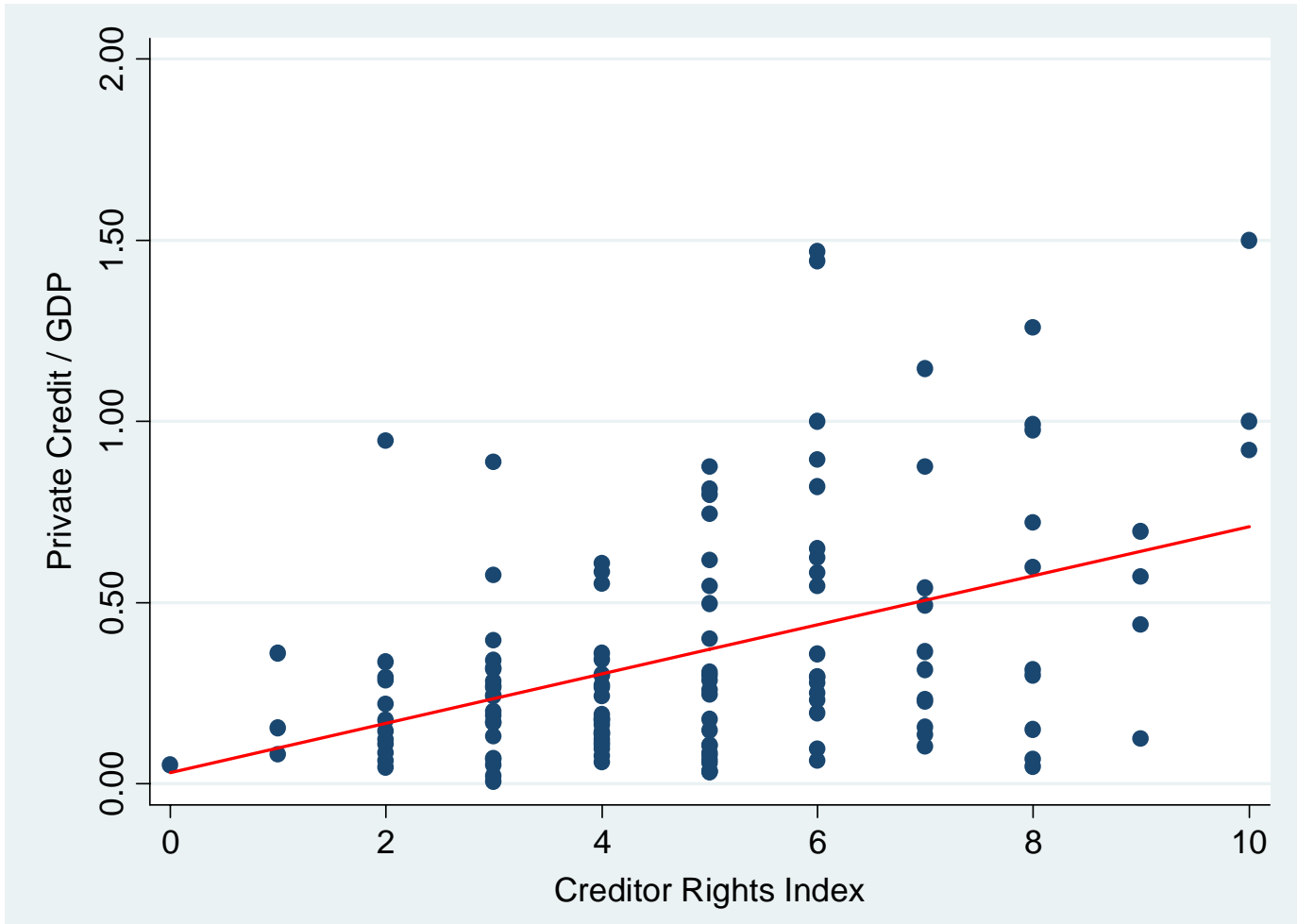




\section{Figure 5: Private Credit and Contract Enforcement}

Private Credit/GDP is the claims of financial institutions on the private non-financial sector to GDP. Data averaged for 1980-2003. Days to Enforce a Contract is an indicators that measure the efficiency of the judicial (or administrative) system in the collection of overdue debt; it is the time required for dispute resolution, recorded in calendar days, counted from the moment the plaintiff files the lawsuit in court until settlement or payment (World Bank, 2005).

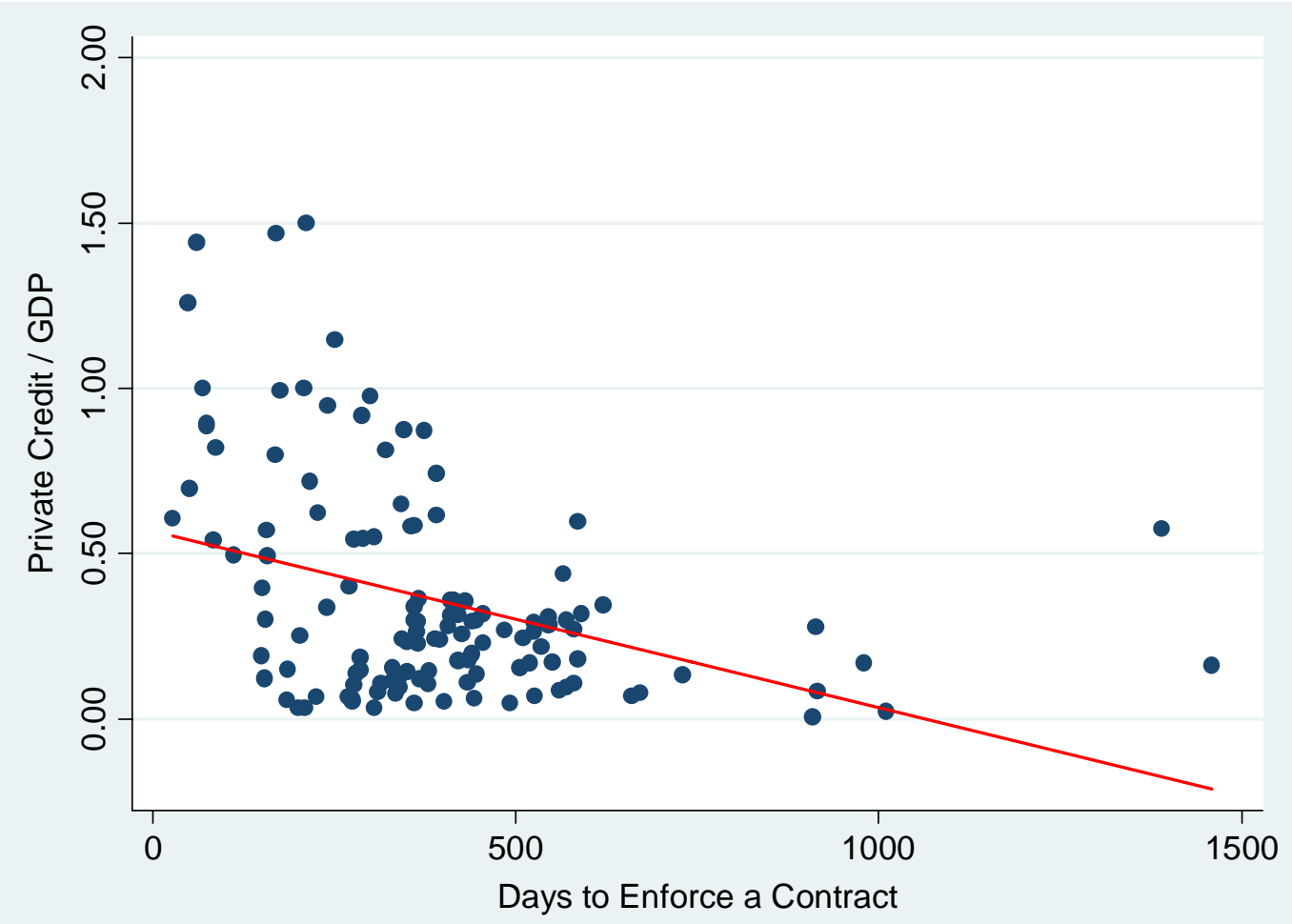


Figure 6: Stock Market Capitalization and Minority Shareholder Rights

Stock Market Capitalization / GDP is the ratio of the value of total shares outstanding to GDP. Data averaged for 1980-2003. Investor Protection Index measures the strength of minority shareholder protections against directors' misuse of corporate assets for personal gain; the index ranges from 0 to 10, with higher values indicating better investor protection (World Bank, 2005).

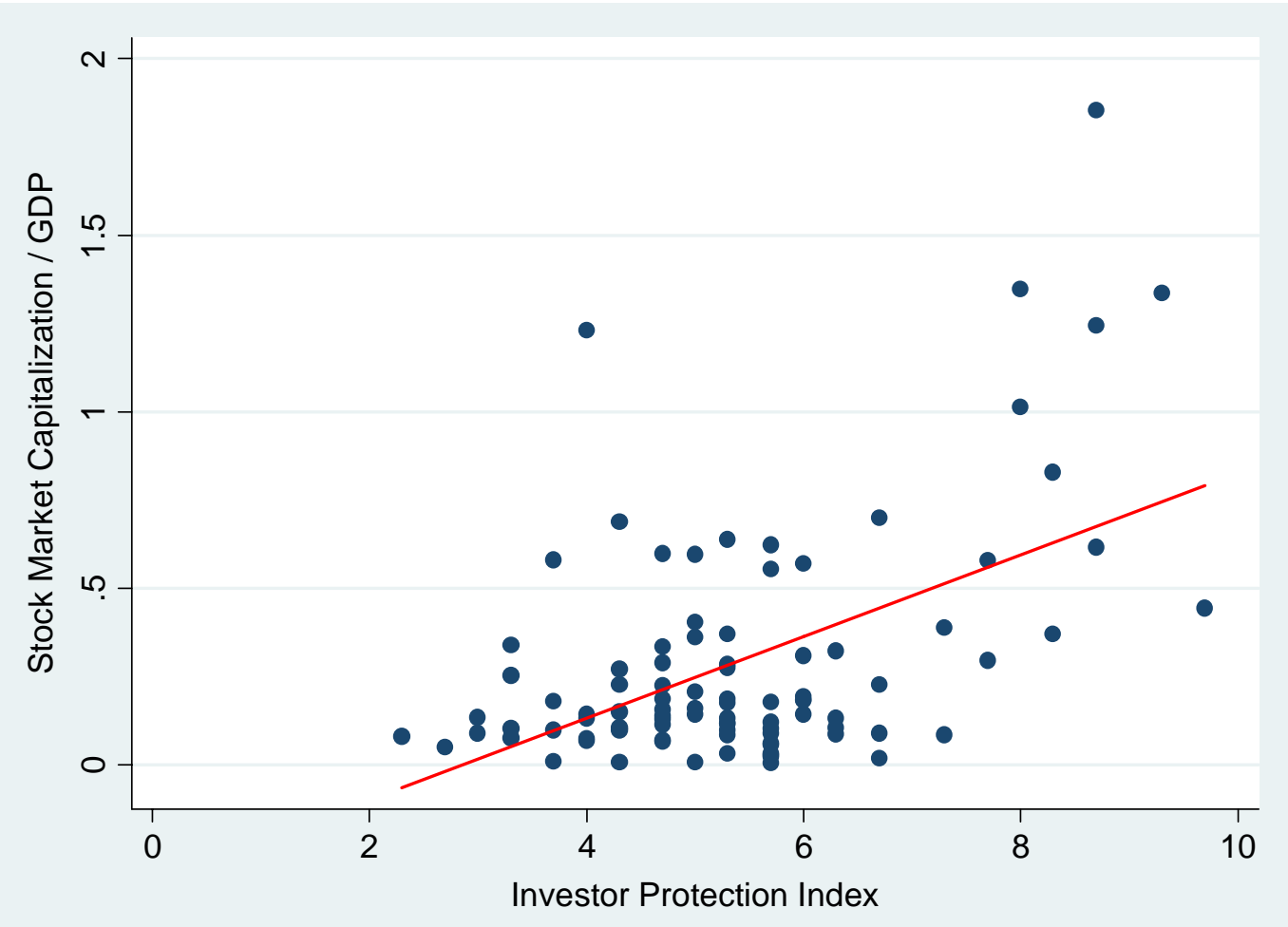




\section{Figure 7: Private Credit and Creditor Information Sharing}

Private Credit/GDP is the claims of financial institutions on the private non-financial sector to GDP. Data averaged for 1980-2003. Credit Information Index measures rules affecting the scope, accessibility and quality of credit information available through either public or private bureaus; the index ranges from 0 to 6 , with higher values indicating that more credit information is available from either a public registry or a private bureau to facilitate lending decisions (World Bank, 2005).

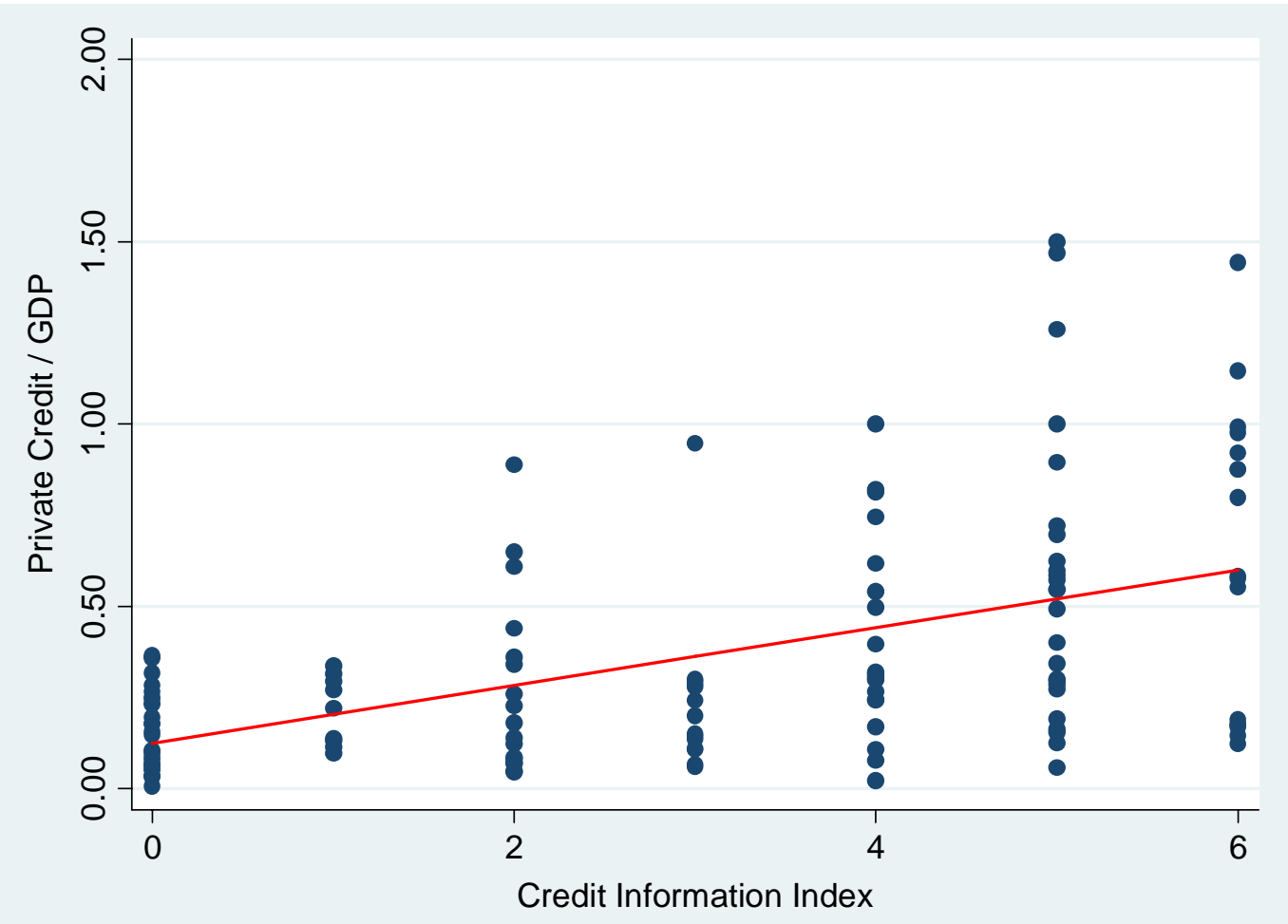


Figure 8: Private Credit and Share of Government-Owned Banks

Private Credit/GDP is the claims of financial institutions on the private non-financial sector to GDP. Data averaged for 1980-2003. Share of Government-Owned Banks is the fraction of the banking system's assets in banks that are $50 \%$ or more government owned (Barth, Caprio and Levine, 2006). Data are for 1997.

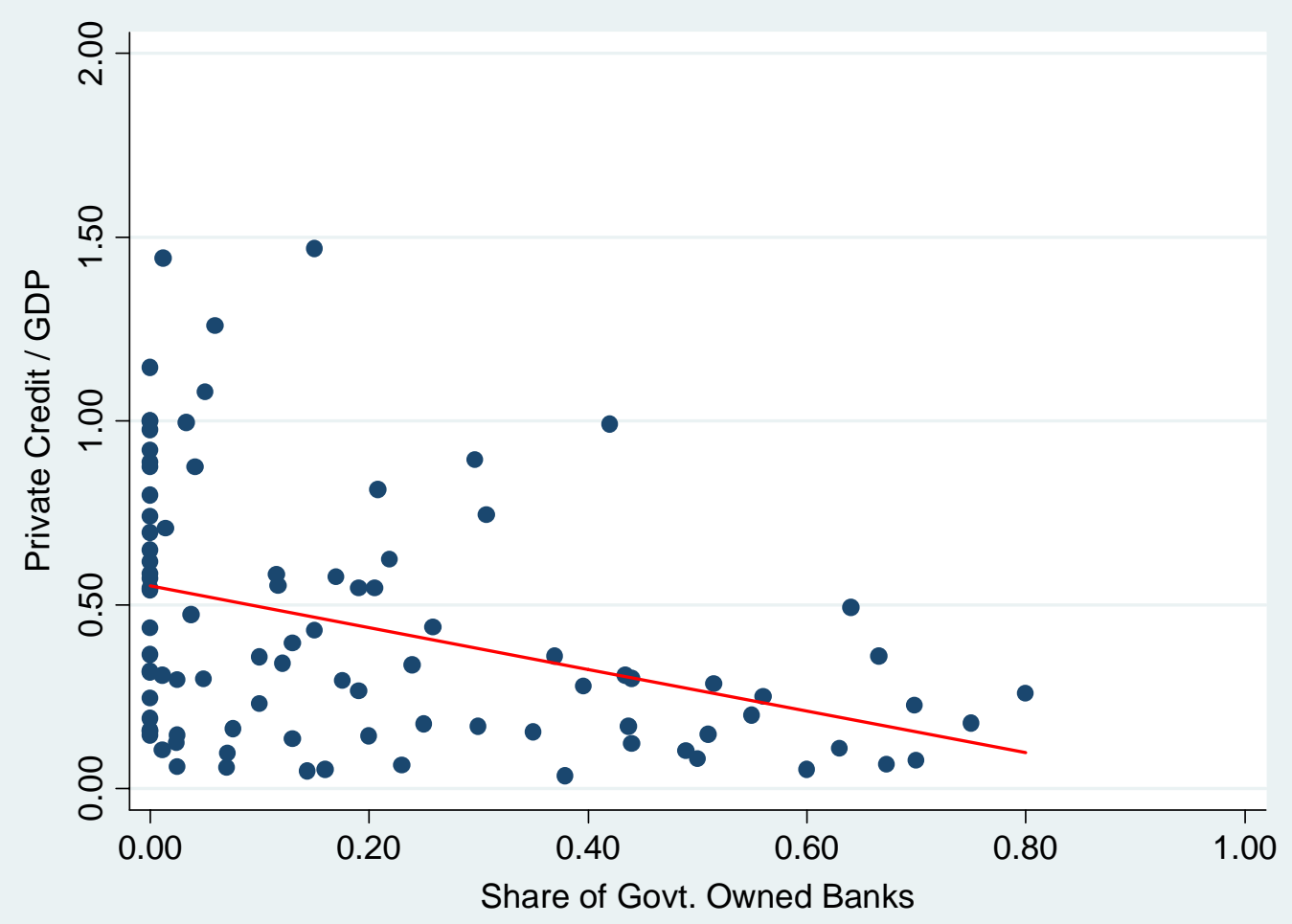

